\title{
Evaluation of Establishment of Oleochemical Industry in Special Economic Zone in Aceh Using SWOT Analysis
}

\author{
Dasmi Husin \\ \{dasmihusin@pnl.ac.id\} \\ Departement of Commerce, Politeknik Negeri Lhokseumawe, Aceh, Indonesia
}

\begin{abstract}
The purpose of this research is to see the opportunities of oleochemical industry establishment in the midst of the plan to establish a special economic area in Lhokseumawe Aceh. This research was conducted in Lhokseumawe and Aceh Utara district. Design / methodology is done by regulation of review, interview, and observation / supervision. Results from structured interviews and collected data were analyzed using qualitative analysis. Researchers analyzed the oleochemical industry market opportunities in a special economic region in Lhokseumawe Aceh using SWOT analysis. The results show that the area of oil palm plantations, human resources, geography, former industrial infrastructure in Lhokseumawe, and openness of the government is very possible established oleochemical industry in the special economic region (KEK) Arun Aceh. This plan will be threatened to be cancelled or transferred to another province when the central government, regional government, and consortium companies do not seriously realize the established development. This study was conducted only to see the SWOT analysis and recording actions taken by the government. Do not see from the side of financial feasibility. Despite these limitations, the findings of this study allow governments, consortium companies, and investors to assist in obtaining a true picture for subsequent decision making.
\end{abstract}

Keywords: Industries, Oleochemicals, Special, Economic, Area

\section{INTRODUCTION}

Today human dependence on fossil fuels is very high. This dependence on fossil fuels is not only used in the transportation sector but also in other primary needs such as clothing, food, and boards. Increased usage raises fears of an energy crisis. These needs continue to increase along with the increase in population, quality and living standards of society, and technology. Although it is also realized that the development of technology can only suppress the energy needs through energy efficiency. If you only rely on the source of fossil raw materials, then there will be obstacles in the fulfilment of energy needs. Therefore another alternative is needed to reduce dependence on petroleum energy sources. One of them is by 
presenting an alternative industry that is oleo chemical industry. Oleo chemistry is a chemical derived from fats and oils. Its products can be used for industrial and household needs.

The oleochemical material can replace petrochemical products. The basic thing that makes oleochemicals can replace petrochemical products is renewable and sustainable oleochemical products. The use of fats and edible oils enables the development of competitive, robust products, and both consumer-friendly and environment-friendly. Oleochemical products have several advantages over mining products such as petroleum, eg oleochemicals derived from renewable resources. It is easier to decompose naturally and socially economically more involving many communities.

If viewed from geographical location, Indonesia has a natural wealth. One of the favorable geographical location is because Indonesia has wide and long coastal areas. Lhokseumawe is on the west coast of the island of Sumatra. The location of this area is very strategic because it is located in the Malacca Strait Marine Lane as an international sea transportation route. This area is also very potential developed profitable agriculture plantations. Sources of plantation products are valuable and easily marketable considering the location of Lhokseumawe demographic and supporting infrastructure is adequate.

With consideration to develop economic activities and utilization of natural resources potential, the Indonesian government through regulation number 5 of 2017 stipulates the area of Lhokseumawe City and the region of North Aceh Regency as a special economic area (KEK). This [1] area has an area of 2,622.48 hectares (ha) located within Arun Lhokseumawe refinery area of 1,840.8 ha. in the Dewantara area of 582.08 ha, and the Jamuan area of 199.6 ha. The location of KEK Arun is temporarily unnecessary for land acquisition because the area and location of KEK are located in the former PT Arun and several other vital projects.

Broadly speaking KEK Arun Lhokseumawe is divided into several zones namely Export Processing Zone, Logistics Zone, Industrial Zone, Energy Zone, and Tourism Zone. The direction of KEK Arun Lhokseumawe activities focuses on several sectors: energy, petrochemical, agro industry supporting food security, logistics and kraft paper producing industries. From the energy sector (oil and gas) will be developed LNG regasification, LNG Hub / Trading, LPG Hub / Trading, Mini LNG Plant PLTG with development of environmentally friendly power plant or clean energy solution provider.

From the results of a temporary review of the addition of new industries is very possible established within the special economic area. The prospect of the oleochemical industry is considered to be very feasible if it is juxtaposed with other chemical factories that have already been present in the region. Both types of oleochemical raw materials are already available in many coastal areas and the highlands of Lhokseumawe and Aceh Utara. Basic infrastructure such as roads, ports, buildings and locations are available. Large-scale national and international companies existed once to form a famous industrial estate. It's just that now many companies no longer operate due to shortage of raw materials of natural gas, internal security disturbances with the state, natural disaster Tsunami, and government policies for the region. These conditions have led to the development of Aceh province lagging behind other regions. Under these conditions of recovery, the government is now planning to establish a special economic zone. Establish a previously lagging region.

According to [2] have been researching the potential of remote areas in Indonesia to be developed into a developed region through strategic regional economic development programs. Important variables that affect these success factors lie in resources, social capital, and local support, entrepreneurial strategies and performance. That is, the contribution of the region itself is the biggest influence in the effort to help the special economic area. This model can give an idea how to form a developing economic area. 
Basically, building a special economic zone in Aceh needs to adopt technological progress. Studying information technology and marketing economics is a must. In addition to the creativity of the business entities themselves, the state also needs to study aspects of global marketing and technology in a continuous improvement effort. The economic and technological management system is a combination of the national strategic planning system. The state can apply the model to build the region.

Learning from China by [1] explains to pursue future prospects, China's Technology Management system always depends on continuous improvement and adjustment. This way can adapt to ever-changing global environment changes. To develop an industry in an area requires a global marketing perspective. Therefore, there must be economic linkage with the establishment of a wide business network. Marketing is closely linked to economic development as it opens up the world marketing system [3]

The presence of a special economic zone in Lhokseumawe, Aceh gives new hope to all parties. Considering the infrastructure of the former factory that is still feasible and the availability of natural resources materials are cheap and easy to obtain, it is suspected the plan to establish an oleochemical industry is very possible. However, to see the existence of the oleochemical industry in the Lhokseumawe KEK region certainly needs to be discussed more deeply. One such form of study can be done by conducting marketing research to assess the benefits, constraints, and opportunities through SWOT analysis. Just as in China to develop new business at the right factory location SWOT analysis is required. According to [4] when determining the exact location required SWOT analysis strategy tool. With SWOT analysis can be explored based on regional infrastructure, local skill level, and cost factor.

This study has not been studied by other researchers because this specific research is in areas of severe natural disasters and former conflict areas of prolonged conflict. This research becomes interesting when the government is also more serious about the development of Aceh because the province has been granted the status as a special autonomous region almost entirely not owned by other provinces. Attract interests between the central government, local government, and the inclusion of a management company appointed as a consortium for the construction of a special economic zone in Aceh is an interesting issue to discuss.

\section{LITERATURE REVIEW}

\subsection{The Need and Selling of Oleochemical Products}

According to [5] describes Oleo chemistry is a derivative of a substantial component of vegetable oil, marine and animal oils and fats, glycerines, glycerol and fatty acids, and includes useful fatty acids. The derivative products of oleo chemicals include fatty alcohols, fatty ester, amides, amines and other nitrogen derivatives as well as heavy metal soaps and water-soluble alkali metal soaps, polyoxyethylene materials, polyoxypropylene products, sulphonated and sulphonated derivatives and quaternary ammonium compounds. Although commonly used in small quantities, but chemical oleo ingredients are important raw materials, additives, to help paint production.

Fatty acids: Fatty acids are the most needed oleochemicals. In general, the production of fatty acids in the world is greater than its consumption. Fatty acids originating and America and Europe are generally synthesized dali tallow, coconut oil, soybean oil, rapeseed oil and others. Fatty acids can be made by splitting CPO or PKO at high temperature and pressure. Further, the fatty acid is distilled or fractionated to obtain high purity fatty acids. Meanwhile, a 
by-product of glycerine after purification will produce glycerine in accordance with the pharmaceutical standard. Derivative products and fatty acids such as fatty ester, fatty alcohol, and other fatty amines are used to replace petrochemical products.

Fatty ester is used as a substitute fuel for diesel oil. The by-product produced in the distillation process and fractionation of high purity metal ester is glycerin which can be used as raw material for pharmaceutical and cosmetic industry. Fatty alcohols: Fatty alcohols are the most widely used basic oleochemicals as surfactant raw materials such as fatty alcohol sulphate (FAS), fatty alcohol ethoxylate (FAE) and fatty alcohol ethoxy sulfate (FAES). Fatty alcohols can be prepared and fatty acids and metal ester by means of hydrogenation at high temperature and pressure using chemical catalyst. Further distillation is performed to produce high purity fatty alcohols.

\subsection{SWOT Analysis and Marketing ProSpects}

SWOT Analysis is a strategic planning method used to evaluate strengths, weaknesses, opportunities (opportunities), and threats in a project or a business speculation. The four factors that form the SWOT acronym (strengths, weaknesses, opportunities, and threats). In it, including personal, financial, manufacturing, and of course 4P (Price, Product, Promote, and Place). While opportunities and threats are external factors that can affect business (macroeconomics, technology, law, culture, and location). SWOT is a simple analytical framework by examining how internal and external factors come together and analyzing the current state.

Before a new business starts first there should be research on whether the business to be pioneered or developed profitable or not. If profitable, is the benefit adequate and can be obtained continuously for a long time? Technically it may be feasible to do so, but economically and socially less benefit. For that, there are two studies or analyzes that can be used to determine whether or not a business is started or developed, namely: a feasibility study of business and SWOT analysis.

SWOT analysis is certainly not absolute because it is necessary also consideration of other factors. There is no easy solution if the analysis is based only on parameters of strengths and weaknesses or threats and opportunities only. At the same time depends also on future developments and specific ideological perspectives [3]. Actually the concept of implicit in society also greatly influences the business concept (Marilyn M. Helms, 1999). Decisionmakers often overlook socio-political aspects such as public acceptance As a result the decision is often incorrect. Therefore, strong relationship mediation is required to avoid gaps in determining market orientation, innovation, and business performance in palm oil processing companies [6].

\section{METHODOLOGY}

This research was conducted in Lhokseumawe and Kabupaten Aceh Utara as the area designated as Economic Zone. Design / methodology / approach is done by regulation of review, interview, and observation / supervision:

- Conducting consultation / interview with government apparatuses such as Head of Subdistrict, Department of Industry, Office of Financial Management and Regional Asset 
(DPKAD), regional secretary of Lhokseumawe City Goverment and Sekda District of North Aceh, and academics, especially State Polytechnic of Lhokseumawe.

- Study of government literature and regulation, and analysis of secondary data from Central Bureau of Statistics (BPS) of Aceh Utara District, BPS of Aceh Province, and mass media.

The results of structured interviews or data that have been collected are analyzed using qualitative analysis. Qualitative assessment uses the data sources as described above. The researchers analyzed and explained the oleo chemical industry market opportunities using SWOT analysis. Several points to be considered are the potential for oil palm in Aceh, the need for oleochemical processed products, the central and regional government policies related to the plan to build a special economic zone in Aceh.

\section{RESULT AND DISCUSS}

\subsection{Potential of Palm Oil Production in Aceh}

The palm oil industry in Aceh is currently in a recovery phase after a period of conflict and natural disasters. This is evident from the small harvest and the limited extent of the garden. It takes a joint effort between interested parties involving government, private sector and society to re-move the palm oil industry. This cooperation seeks to produce and promote the development of sustainable palm oil in Aceh within the framework of the Roundtable on Sustainable Palm Oil (RSPO).

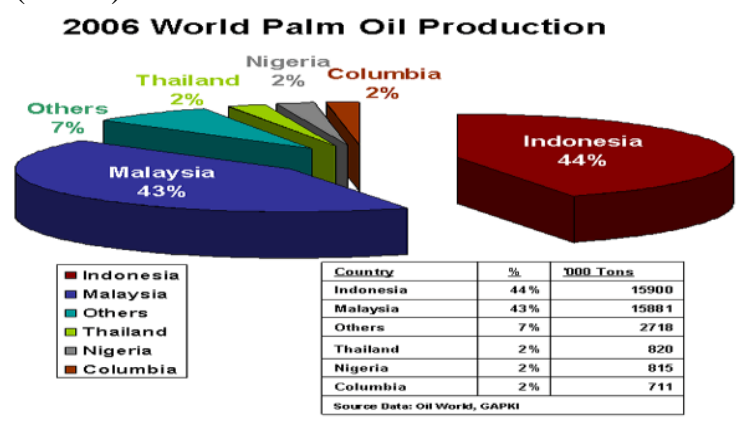

Fig. 1 World Palm Oil Production

In Indonesia the island of Sumatra has long been the largest producer of palm oil in Indonesia. Aceh province participated. Although the producers of palm oil are relatively small and contribute less than 3 percent of national production, Aceh has never been a pioneer of oil in Indonesia. The palm oil industry in Aceh is centered on five districts along the western and eastern coasts, namely Aceh Utara, East Aceh, Aceh Tamiang, Nagan Raya, and Aceh Singkil (including the Subullusalam municipality). These six districts and municipalities have more than $84 \%$ of the total hectares of cultivated land and their production [7].

During the conflict period, an estimated 85,000 hectares or $33 \%$ of the total land $(52,712$ hectares of smallholders and 32,316 hectares of large estates) were abandoned or abandoned. Many small farmers, especially transmigrate from outside Aceh, can not live on plantations. Much of the palm oil production area is sufficiently affected by the conflict, while 
approximately 21,000 hectares are less or less affected by the Tsunami. Even when the price of fresh fruit bunches from oil palm is bought down for palm oil processing, people are willing to sell cheaply. The community does not know that there is no alternative to palm oil processing, namely palm oil derivatives, ie, oleochemicals that can be traded.

Although the potential of the palm oil industry is huge, in Aceh there is currently no secondary processing plant for palm kernel oil or refineries. The feeder port or tank warehouse for practical storage does not exist. It includes the palm oil-based food industry, biodiesel, oleochemical plant and surfactant, and complete port facilities. Therefore, Aceh is still more a producer of raw materials, with local prices relatively depressed due to logistical barriers and quality barriers previously mentioned. As a result, practically all production is currently sold as a domestic product and is exported indirectly through the Belawan port in North Sumatra.

\subsection{Prospect of Oleochemicals Industry}

International commodities research data showed during the period 2010-2020, the oleochemical market is expected to grow 3.6 percent for fatty alcohol and four percent for fatty acids. The growth record is the largest in Asia. Indonesia and Malaysia will become the largest oleochemical producers in the world. To support the prospect, the Indonesian government needs to limit the export of crude palm oil (CPO) gradually to support the downstream industry in the country. Therefore, it is necessary to build CPO-based industrial clusters. The market opportunity for CPO derivative products, especially oleochemicals for the national industry, is enormous. This is because world demand continues to increase.

Although the condition of Indonesia's infrastructure is not sufficient, the prospect of the oleochemical industry is very promising as demand in the world market continues to improve. With such world demand conditions, there should be a government policy that ensures the availability of raw materials in the form of crude palm oil and palm kernel oil (PKO) in the country. That is, the current export of crude palm oil is restricted so that the refinery runs well and (industrial) oleochemicals can thrive. Without the government's policy of limiting CPO exports, it is feared that Indonesia as the largest producer of CPO will become the largest importer of oleochemicals. The added value of oleochemical products is very high compared to CPO. The added value of the product reaches US \$400-1,200. Unfortunately not many companies in Indonesia go into the oleochemical industry.

On the other hand, the government's attention to infrastructure for the development of the oleochemical industry is still limited. The problem is the oleochemical industry requires adequate infrastructure. For example the port used for export abroad. To be more directed, good communication between departments (government), consortium business entities, local governments, and communities to support the development infrastructure of the oleochemical industry. One of them is by establishing special economic area as planned in Lhokseumawe, Aceh.

Researchers such as [8] have conducted surveys conducted in the palm oil processing sector in Malaysia, consisting of grinding, refining and oleochemical companies. Organizational resources have a direct impact on the presence of the chemical oleo industry. It is necessary to promote business performance in the palm oil processing sector characterized by the ability to access organizational resources for better business performance. 


\subsection{Perspectives of KEK Aceh and its Problems}

Although the government has issued regulations, special economic zones (KEK) in Aceh have not been running. In fact now many parties complain about the available infrastructure. For example in the harbor the number of cranes and warehouses is very limited. The existing warehouse is also considered not feasible. These obstacles need to be addressed immediately if you want to talk export and import business because KEK actually depends on the availability of infrastructure. With the existence of adequate infrastructure will give birth to various industries. Both small and large scale industries.

Not yet fully run normally, the presence of KEK Arun Lhokseumawe also raises internal problems from Aceh. The acceleration team for the development of Arun Lhokseumawe Special Economic Zone requested to be revised again Government Regulation No. 5 of 2017 due to inconsistency of share participation. The Government of Aceh is considered to have only the authority to establish a consortium of development and management of the Lhokseumawe KEK only. While those who run the development and manage it is a consortium company. This means that the central desire to involve the Aceh Government is still limited. The plan is that the Aceh Government wants to make the assets of the Arun LNG plant as the initial capital for the Government of Aceh, the Government of North Aceh, and the Lhokseumawe Government in the Management Agency of KEK Arun Lhokseumawe. Provided that the assets of former LNG refinery remain state-owned under the State Asset Management Agency, the management is handed over to the Aceh Government, North Aceh Regency Government and Lhokseumawe Municipal Government.

In article 6 of Government Regulation No. 5 of 2017 only regulates the Business Development Agency of KEK Arun Lhokseumawe, while the Management Board as mentioned in Article 5 is not regulated. The appointment of the consortium company itself is not based on a share holder agreement governing in detail the governance, duties and obligations of the parties, but only based on the Memorandum on Understanding (MoU) signed by the respective directors of each consortium company and the Company Regional Government of Aceh (PDPA). In the MoU the Aceh Government shares represented by PDPA as the party that has been approved to be given the right to manage only 25 percent. Its share ownership is in the form of capital payments sourced from the Aceh government budget or other sources. In essence, the Government of Aceh wants the existence of goodwill as the party given the right to manage is calculated as the participation of capital. The share of each share is 25 percent for Aceh, considered to be a fair share of the numbers but does not meet the sense of justice for the people of Aceh. Therefore, the government is asked to revise the government regulation it has issued.

From the hard work of the Aceh government, it was later learned that Aceh Province through the Aceh Oil and Gas Management Agency (BPMA) has obtained 46\% share approval in the management of Special Economic Zone (KEK) Arun. This means that the share of Aceh has increased $21 \%$ from the previous amount only 25\% [9]. The Aceh government claimed to have asked members of the KEK Arun consortium to reduce their shares. Members of the consortium finally agreed to reduce their share of the stake in the management of KEK Arun 7\% each to be given to the Aceh government so that the share of Aceh now has $46 \%$. The above recognition will be reliable if it has been accompanied by a revision of government regulations. The $46 \%$ share of new shares is convincing if it is actually written in the latest regulations issued by the government. 


\subsection{SWOT and Potential Marketing Analysis}

Building an integrated industrial area should analyze the market and the environment thoroughly in order to be able to apply further strategies to conduct further marketing activities and achieve the highest level of customer satisfaction.

Table 1. SWOT Analysis

\begin{tabular}{|c|c|}
\hline Strenght & Opportunities \\
\hline 1. Community interest for oil palm plantation is very & 1. The market of oleo chemical products both \\
\hline 2. Available skilled manpower produced by nearby & 2. Land for coconut and oil palm is still very wide \\
\hline campus & 3. The government has set up Aceh province as a \\
\hline 3. Experience and introduction of oil palm plantations & special economic zone (KEK) which will build \\
\hline have been long & ture supp \\
\hline 4. Palm oil is easy to grov & chemical industry \\
\hline $\begin{array}{l}\text { conditions compared to other plants } \\
\text { 5. Close to air, sea and land transportation routes }\end{array}$ & $\begin{array}{l}\text { 4. New oleo chemical industries / plants } 6 \text { new } \\
\text { companies. }\end{array}$ \\
\hline $\begin{array}{l}\text { 6. Being in the former industrial area of international } \\
\text { standard }\end{array}$ & $\begin{array}{l}\text { 5. Foreign trade routes (exports) to the most oleo } \\
\text { chemical user countries are very close }\end{array}$ \\
\hline $\begin{array}{l}\text { 7. Sufficient power supply available from Perta Gas } \\
\text { Arun (PGA) Aceh refinery }\end{array}$ & \\
\hline 8. The special autonomy authority of Aceh Province & \\
\hline & \\
\hline Weakness & Treat \\
\hline 1. Need big investment to build oleochemical industry & 1. Canceled the decision of KEK Arun Aceh \\
\hline 2. Support from the government and national head of & 2. Assistance from local governments to build KEK \\
\hline the policy of oleo chemical industry development & 3. The oleo chemical industry is likely to be \\
\hline 3. Regulation and job synchronization between central & established in other provinces because the \\
\hline $\begin{array}{l}\text { government, local government, and consortium } \\
\text { companies are still slow. }\end{array}$ & difficult to determine world market pr \\
\hline 4. Until now there has been no infrastructure & to unavailability of market information \\
\hline $\begin{array}{l}\text { development in connection with the plan of KEK } \\
\text { Arun Aceh }\end{array}$ & $\begin{array}{l}\text { 5. People are not familiar with the prospect of the } \\
\text { oleo chemical industry }\end{array}$ \\
\hline
\end{tabular}

The land area and the production of coconut and oil palm in Aceh Utara district and Lhokseumawe City Government are relatively stable from year to year. While the land that has not been utilized for plantations is still quite extensive. Raw materials in the form of coconut and oil palm can also be obtained from other districts in Aceh. Cheap and easy to get the material. Stakeholders involved in the development of oil palm commodities are optimistic that coconuts in Aceh can still flourish. Because of that sufficiency, the oleochemical industry in Aceh is very possible to be established.

The oleochemical industry and the presence of special economic zones (KEK) in Lhokseumawe are believed to have a positive impact on regional development. In addition to growing the investment climate, SEZ development can also reduce unemployment. This Special Economic Zone will require tens of thousands of skilled workers from various disciplines. These needs are believed not to be a problem because Lhokseumawe already has a college institution that produces skilled and qualified graduates. One of them is a graduate of Lhokseumawe State Polytechnic. The educational model in the institution of higher education is prioritizing the vocational education system that prioritizes operational skills rather than 
conceptual mastery. Polytechnic Alumnus is skilled and ready to be employed in various fields.

The SEZ location is located around the national road. From the distance side of the transportation range this location can be visited easily. Some basic infrastructure such as Malikussaleh Airport and Kruenggukueh port are already available. The infrastructure certainly needs improvement and addition. Roads need to be widened, railways need to be built, airports have not been expanded, the number and feasibility of storage warehouses is also worth noting. All stakeholders should work hard to realize the SEZ. If this is not handled seriously and quickly, it may be that the determination of the Aceh Arun Regions was canceled and transferred to other provinces.

From the analysis of marketing study using SWOT analysis, the plan to build oleochemical industry in Lhokseumawe Special Economic Zone (KEK) is very potential to be implemented. Not because of this area as a former natural disaster area, a former area of security conflict, or because this area has special autonomous region status, but from resource factor, social capital, government support, and preparedness of available infrastructure, special. Requirement to wake up first the special economic area. Aceh province may contribute to market participants in the oleochemical industry. This area also enables very well established industrial zones and export processing zones to reach the marketing area to worldwide.

\section{Conclusions}

The feasibility of building an oleochemical industry depends very much on the plan to build a special economic zone. The key to the success of the Special Economic Zone program (KEK) of Arun Lhokseumawe lies with the Builder and Management Enterprise (BUPP). It is in accordance with Article 5 paragraph (2) PP No. 5 of 2017 stating that BUPP is responsible for financing the construction and management of the KEK Arun Lhokseumawe. It is desirable that the commitment of the consortium of State-Owned Enterprises and AcehOwned Enterprises to immediately complete the development of Special Economic Zone (KEK) Arun Lhokseumawe.

This study was conducted only to see the SWOT analysis and recording actions taken by the government. This research should also look at the financial feasibility side. Despite these limitations, the findings of this study allow governments, consortium companies, and investors to assist in obtaining a true picture for subsequent decision making.

\section{References}

[1] H. Wang and Y. Hong, "China: technology development and management in the context of economic reform and opening," J. Technol. Manag. China, vol. 4, no. 1, pp. 4-25, 2009.

[2] G. Marquis, "Journal of Enterprising Communities: People and Places in the Global Economy For Authors," J. Enterprising Communities People Places Glob. Econ. Iss, vol. 3, no. 4, pp. 355-368, 2009.

[3] L. Jaakkola, E., Helkkula, A., Aarikka-Stenroos, “Article information :," J. Serv. Manag., vol. 26, no. 2, pp. 182-205, 2015. 
[4] M. M. Helms, "How to be successful in China: A SWOT Analysis," Compet. Rev. An Int. Bus. J., vol. 9, no. 2, pp. 1-10, 1999.

[5] E. S. Lower, "Oleo chemicals as additives in paints and varnishes, etc: Part 2," Pigment \&amp; Resin Technol., vol. 20, no. 1, pp. 10-17, 1991.

[6] Y. Chong Tan, F. Mavondo, and S. Worthington, "Organisational capabilities and relationship quality,” Asia Pacific J. Mark. Logist., vol. 23, no. 2, pp. 152-164, 2011.

[7] Thomas B. Fricke, "Penggunaan Limbah Dan Produk," no. 497, pp. 1-105, 2009.

[8] Y. Chong Tan and N. Oly Ndubisi, "Evaluating supply chain relationship quality, organisational resources, technological innovation and enterprise performance in the palm oil processing sector in Asia," J. Bus. Ind. Mark., vol. 29, no. 6, pp. 487-498, 2014.

[9] Serambi Indonesia, “Aceh Can 46\% Share in KEK Arun,” July 13, 2017, 2017. 